\title{
A Laboratory Manual of Qualitative Organic Analysis
}

\section{H. T. OPENSHAW}

A practical guide, for use on the bench, to the identification of the commoner types of organic compound, consisting of a series of tests for functional groups, to be applied in a definite order. Experience gained in the use of the book since it was first published in 1946 has made necessary some minor corrections and has suggested some improvements which are incorporated in this new edition.

IOs. 6 d. net

\section{CAMBRIDGE UNIVERSITY PRESS}

\section{The Quarterly Journal of Medicine}

Edited by W. RUSSELL BRAIN, CRIGHTON BRAMWELL, W. D. W. BROOKS, D. M. DUNLOP, H. L. MARRIOTT, ROBERT PLATT

\section{CONTENTS}

NEW SERIES. VOL. XXI. No. 81. JANUARY 1952

(Vol. XLV of the continuous series)

The Hæmopoietic Activity of Folic Acid Treated with Xanthine Oxidase. By W. JACOBson and Phyllis M. Good.

A Familial Disorder of Blood Coagulation Due to Deficiency of the Labile Factor. By A. J. Brink and C. S. KingSLEY.

Osteomalacia and Renal Glycosuria in Adults: Metabolic Investigation of a Case with Particular Reference to its Relation to the Fanconi Syndrome and to Treatment. By IAN A. ANDERson, Alexander Miller and Andrew P. Kenny. With Plates 1 and 2.

Observations on the Fanconi Syndrome and Renal Hyperchloræmic Acidosis in the Adult. By M. D. Milne, S. W. Stanbury and A. E. Thomson. With Plate 3.

Certain Aspects of the Medical Application of Isotopic Tracers. By G. PopJÁk.

Single Numbers $12 \mathrm{~s} .6 \mathrm{~d}$. net each Subscription 40 s. per annum Subscription, Bound Volumes 45 s. net

OXFORD UNIVERSITY PRESS, LONDON E.C. 4 


\section{CON TEN T S \\ (All rights reserved)}

Moore, B., Perry, E. L. and Chard, S. T. A survey by the sewage swab method of latent enteric infection in an urban area. (With 4 Figures in the Text) . 137

BENNETT, B. M. Estimation of LD 50 by moving averages _ . • • • $\quad$ - 157

INGRAM, M. Internal bacterial taints ('bone taint' or 'souring') of cured pork legs. 165

Henderson, W. M. A comparison of different routes of inoculation of cattle for detection of the virus of foot-and-mouth disease $\quad$ - $\quad . \quad$.

Henderson, W. M. Significance of tests for non-infectivity of foot-and-mouth

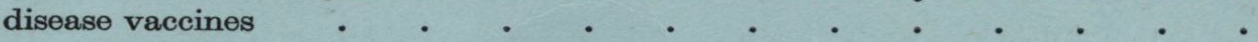

Sharpe, M. Elisabeth. Group D streptococci in the faeces of healthy infants and of infants with neonatal diarrhoea. (With 3 Figures in the Text). . . .

HoYLE, L. Structure of the influenza virus. The relation between biological activity and chemical structure of virus fractions . $\quad . \quad$. $\quad . \quad$. . . .

Alexander, M. B., Benjamin, B., Maslen, L. G. C. and Roden, A. T. Streptomycin treatment of infantile diarrhoea and vomiting. Conduct and results of a controlled trial

Fulton, Forrest. The titration of influenza virus-neutralizing antibodies. (With 2 Figures in the Text)

The Journal of Hygiene is issued in four parts to a volume.

Quotations can be given for back volumes on application.

Papers for publication should be sent to Professor E. T. C. Spooner, London

School of Hygiene and Tropical Medicine, Keppel Street, Gower Street, London, W.C. 1.

Other communications should be addressed to the University Press, Cambridge.

Papers forwarded to the Editor for publication are understood to be offered to The Journal of Hygiene alone, unless the contrary is stated.

Contributors receive fifty copies of their papers free. Additional copies may

be had at cost price: these should be ordered when the final proof is returned.

Commencing with Vol. 50 the subscription price will be $£ 4$ per volume (post-free), payable in advance; single numbers $22 s .6 d$. net. Subscriptions may be sent to any Bookseller, or to The Cambridge University Press, Bentley House, 200 Euston Road, London, N.W. 1.

The subscription price in the U.S.A. is \$13.50. Single parts $\$ 3.75$. Enquiries should be addressed to the American Branch of the Press at 32 East 57th Street, New York, 22. 